\title{
REFORMASI BIROKRASI SEBAGAI UPAYA MEWUJUDKAN GOOD GOVERNANCE MELALUI KERANGKA OTONOMI DAERAH
}

\author{
Rifi Rivani Radiansyah \\ Fakultas Ilmu Sosial dan Politik, Universitas Bale Bandung \\ email: Rifirivani@unibba.ac.id
}

\begin{abstract}
Bureaucratic reform which initially existed to support the success of regional autonomy, in practice often creates inconsistency problems which actually give birth to paradoxes. So it happened in West Bandung Regency. On the other hand, the bureaucracy improves itself through the implementation of bureaucratic reform, but on the other hand it slows down the progress of the bureaucracy with the practice of corruption. This paper aims to find out the problems of bureaucratic reform and to find out whether the implementation of bureaucratic reform has shown optimal results in West Bandung Regency. This paper review uses qualitative methods through empirical normative-juridical approach and institutional theory approach. Data collection is done by official document collection techniques. Data analysis techniques in this study were carried out using interpretive descriptive methods. The results of the study in this paper show that the bureaucratic reform carried out by the West Bandung regency government through the practice of regional autonomy has not shown signs that are more optimal in the effort to realize Good Governance. Normatively, this condition is caused by the still low quality (competency) of apparatus resources, accompanied by other things that are mimetic and coercive which also influence the apparatus mentality as a whole based on their interests such as the influence of leadership, culture and the bureaucratic environment.
\end{abstract}

Keyword: bureaucratic reform; good governance; regional autonomy.

\begin{abstract}
ABSTRAK
Reformasi birokrasi yang awalnya ada untuk mendukung keberhasilan otonomi daerah, pada praktiknya seringkali menimbulkan problem inkonsistensi yang justru melahirkan paradoks. Demikian hal itu terjadi di Kabupaten Bandung Barat. Disisi lain, birokrasi memperbaiki diri melalui pelaksanaan reformasi birokrasi, namun disisi lainnya lagi memperlambat kemajuan birokrasi dengan adanya praktik korupsi. Tulisan ini bertujuan untuk mengetahui permasalahan reformasi birokrasi dan untuk mengetahui apakah pelaksanaan reformasi birokrasi telah menunjukan hasil capaian yang optimal di Kabupaten Bandung Barat. Kajian tulisan ini menggunakan metode kualitatif melalui pendekatan yuridis normatif-yuridis empiris dan pendekatan teori institusional. Pengumpulan data dilakukan dengan teknik pengumpulan dokumen resmi. Adapun teknik analisis data dalam kajian ini dilakukan dengan menggunakan metode deskriptif interpretatif. Hasil kajian dalam tulisan ini menunjukan, reformasi birokrasi yang dijalankan pemerintah daerah Kabupaten Bandung Barat melalui praktik otonomi daerah belum menunjukan tanda-tanda ke-arah yang lebih optimal didalam upaya mewujudkan Good Governance. Secara normatif, kondisi demikian disebabkan masih rendahnya kualitas (kompetensi) sumber daya aparatur, disertai dengan hal lainnya yang bersifat mimetic dan koersif yang juga turut memengaruhi mentalitas aparatur secara keseluruhan berdasarkan kepentingannya seperti pengaruh pimpinan, budaya dan lingkungan birokrasi.
\end{abstract}

Kata Kunci: reformasi birokrasi; good governance; otonomi daerah. 


\section{PENDAHULUAN}

Memasuki era reformasi, Indonesia melakukan beberapa pembenahan dalam pengaturan tata pemerintahan. Salah satu diantaranya adalah penetapan dan penerapan sistem desentralisasi yang sekaligus juga menandakan dimulainya era otonomi daerah. Desentralisasi dan otonomi daerah merupakan bagian tidak terpisahkan dari agenda reformasi birokrasi gelombang pertama yang diterapkan guna memaksimalkan kinerja birokrasi di setiap daerah menjadi lebih efektif dan efisien (Thoha, 2014, hal. 82). Namun demikian, seiring dengan berjalan penerapannya, ternyata tidak serta merta membawa perubahan birokrasi di daerah kearah yang lebih baik. Hal itu ditandai dengan masih melekat kuatnya birokrasi sebagai pamong akibat warisan budaya patrimonial di tubuh birokrasi, yang membawa ekses negatif dalam bentuk patologi birokrasi (Mariana, 2006).

Tidak sedikit juga kecenderungan itu mengakibatkan pola rekrutmen sumber daya manusia aparatur menjadi tidak kompetitif dan tidak profesional (Lestari, 2019), ditambah lagi dengan makin maraknya praktik korupsi di daerah yang disebabkan lemahnya pengawasan dan struktur kepemimpinan yang tidak tegas (Moenek \& Suwanda, 2019). Dari berbagai persoalan demikianlah kemudian menjadi cikal bakal diterapkannya kebijakan reformasi birokrasi gelombang kedua melalui Peraturan Presiden No.81 Tahun 2010 tentang Grand Design Reformasi Birokrasi 2010-2025 (GDRB). Tujuannya, guna memberikan arahan yang lebih spesifik agar reformasi birokrasi pada tataran kementerian/lembaga, dan pemerintah daerah dapat berjalan secara efektif, efisien, terukur, konsisten, terintegrasi, melembaga, serta berkelanjutan dalam mewujudkan Good Governance (Sugiharto, 2011).

Adanya kebijakan tersebut tentu memberikan harapan baru terkait perbaikan tata kelola birokrasi di daerah. Hanya saja, cenderung menjadi terkesan longgar tatkala dijalankan melalui prinsip-prinsip penyelengaraan desentralisasi-otonomi daerah. Itulah yang kemudian tidak sedikit persoalan "inefisiensi" maupun "inkonsistensi" pada akhirnya memunculkan paradoks yang berpotensi menghambat keberhasilan agenda reformasi birokrasi itu sendiri (Jati, 2012). Pemerintah daerah yang di sisi lain mengemban amanat (nilai) masyarakat, dengan upayanya memberikan perubahan ideal di tubuh birokrasi melalui semangat penyelenggaraan otonomi daerah, namun di sisi lain, mereka juga (aparatur pemerintah) yang pada akhirnya memupus harapan itu sendiri (Ismail, 2017).

Kondisi demikianlah yang kontras terjadi di Kabupaten Bandung Barat. Fenomena korupsi yang secara langsung melibatkan pejabat Bupati Kabupaten Bandung Barat periode 2013-2018 pada awal 2018 lalu (Tim Tagar.id, 2018), disusul oleh para pejabat lainnya pada kasus yang hampir serupa dengan motif yang berbeda (detikNews, 2019; Bebey, 2019), kontras menggambarkan bahwa, penyelenggaraan pemerintahan daerah Kabupaten Bandung Barat sedang dalam keadaan tidak baik-baik saja. Agenda reformasi birokrasi yang dijalankan sejauh ini, seolah isomorfisme koersifi yang diselenggarakan hanya formalitas, mengabaikan hal yang cenderung normatif berkaitan dengan keprofesionalitasan aparatur (Sofyani \& Akbar, 2015).

Padalah secara normatif, kebijakan reformasi birokrasi yang dijalankan saat ini telah memberikan ketentuan yang sebetulnya jauh lebih ketat, mengamanatkan beberapa sasaran-sasaran penting yang semestinya diupayakan lebih optimal sebagai penunjang keberhasilan praktik penyelenggaraan otonomi daerah, yang antara lain, birokrasi yang bersih dan akuntabel, birokrasi yang efektif dan efisien, serta birokrasi yang memiliki pelayanan publik berkualitas. Ketiga point tersebut merupakan kunci mewujudkan good

\footnotetext{
1 Coercieve Isomosphism merupakan istilah yang di kemukakan Di Maggio dan Powell dalam teori Institusionalnya. Kondisi ini menggambarkan dimana adanya tekanan-tekanan kuat dari organisasi lain agar organisasi yang bersangkutan melakukan perubahan (tekanan tersebut dapat bersifat formal maupun informal).
} 
governance berdasarkan grand design reformasi birokrasi, yang mana untuk mewujudkan ketiga sasaran itu telah ditetapkan beberapa area perubahan sebagai fokus utama perbaikan birokrasi yakni, mental aparatur, pengawasan, akuntabilitas, kelembagaan, tatalaksana, sumberdaya aparatur, peraturan perundang-undangan, dan pelayanan publik (Sugiharto, 2011).

Namun, yang menjadi penting untuk diperhatikan disini bahwa, ketentuan agenda reformasi birokrasi tersebut pada tataran teknis penyelenggaraannya justru semestinya secara normatif harus dilaksanakan melalui praktik otonomi daerah yang penuh dengan kesadaran kolektif aparatur. Mengingat bahwa, praktik otonomi daerah dalam perspektif pembangunan di daerah sebagian besar bergantung pada kualitas dan kemampuan untuk mengolah beberapa faktor-faktor kunci seperti, manusia pelaksananya, faktor organisasi dan manajemen, faktor pendukung kinerja (keuangan daerah \& peralatan/instrument/sarana-prasarana) (Radiansyah, 2019). Maka dari itu, untuk mengolah instrument tersebut agar menghasilkan dampak positif bagi kepentingan masyarakat di daerah, reformasi birokrasi sudah seyogiyanya menjadi prioritas sangat penting, yang harus diperhatikan sebagai penunjang juga sebagai upaya untuk terus menerus memperbaiki kualitas dan kapasitas aparatur pelaksana dalam penyelenggaraan pemerintahan di daerah guna mewujudkan tujuan daripada agenda pembangunan nasional menuju good governance menjadi lebih efektif.

Yang menjadi pertanyaan dan akan dibahas dalam kajian ini yakni, bagaimanakah sejauh ini reformasi birokrasi di daerah pada level kabupaten/kota, khususnya di Kabupaten Bandung Barat sebagai upaya mewujudkan good governance melalui kerangka otonomi daerah, dan kemudian apakah sejauh ini reformasi birokrasi yang dilaksanakan telah menunjukan hasil capaian yang optimal. Adapun tujuan yang hendak dicapai dalam tulisan ini yakni, untuk dapat mengetahui/memberikan gambaran adanya jarak/gap (kesenjangan) antara harapan dan kenyataan melalui gambaran deskriptif yang lengkap, baik dalam bentuk verbal maupun numerical mengenai jalannya reformasi birokrasi di Kabupaten Bandung Barat dan kemudian juga untuk dapat mengetahui apakah agenda reformasi birokrasi yang dilaksanakan pemerintah daerah Kabupaten Bandung Barat telah menunjukan hasil capaian yang optimal saat ini sebagai upaya mendukung terwujudnya good governance.

\section{TINJAUAN PUSTAKA}

Reformasi Birokrasi merupakan salah satu upaya pemerintah untuk mencapai good governance $^{2}$ dan melakukan pembaharuan serta perubahan mendasar terhadap sistem penyelengaraan pemerintahan terutama menyangkut aspek-aspek kelembagaan (organisasi), ketatalaksanaan, dan sumber daya manusia aparatur (Moenek \& Suwanda, 2019). Secara substantif, reformasi birokrasi diproyeksikan untuk mengatasi persoalan publik, lingkungan administrasi publik, perubahan struktural dan institusi, serta perubahan tingkah laku aparatur baik individu maupun kelompok atau kombinasi dari keduanya (Satibi, 2012). Sedangkan dalam perspektif pemerintahan daerah, reformasi birokrasi sebagai perubahan yang terencana, sistematis dan terukur dalam rangka mengubah tatanan pemerintahan daerah, agar mampu menciptakan sistem pemerintahan yang transparan, akuntabel, dan bersih (Dwiyanto, 2010). Hal tersebut berhubungan erat dengan praktik penyelengaraan otonomi daerah berdasarkan prinsip desentralisasi yang berarti

\footnotetext{
2 Konsep Good Governance tidak terlepas dari perubahan paradigma awal dari "Government" ke "Governance" dalam Sedarmayanti, Good Governance, "Kepemerintahan Yang Baik", Bag-2 Edisi Revisi, Cetakan ke-2 (Bandung:CV.Mandar Maju.2012),hlm.1-4. Kendatipun Good Governance hingga sampai saat ini masih dianggap sebagai konsep yang abstrak bahkan hampir dapat dikatakan utopis, namun secara ontologis-axiologis nilai-nilai keberhasilannya berusaha terus diupayakan berdasarkan kategori-kategori dan pendefinisiannya secara eksplisit. Lihat dan baca interpretasinya dalam Mudiyati Rahmatunnisa, "Dialektika Konsep Dynamic Governance",Volume 02.No.02, Agustus 2019.,hlm.3-4.
} 
pemerintah lebih banyak memberikan kepercayaan dan pemberdayaan kepada daerah agar mampu berpemerintahan dan berotonomi mengatasi persoalan-persoalan daerahnya, termasuk juga salah satunya dalam menyelenggarakan serangkaian agenda kegiatan reformasi birokrasi secara mandiri (Thoha, 2014).

Kajian dan riset yang berkaitan erat dengan reformasi birokrasi yang dibahas dalam tulisan ini sebetulnya sudah cukup banyak dilakukan banyak peneliti lainnya. Hanya saja sedikit peneliti yang menyinggung keterkaitannya secara langsung dengan praktik otonomi daerah, meskipun memang sampai sejauh ini kajian reformasi birokrasi yang ada lebih banyak dilihat dari perspektif administrasi negara, administrasi publik, model kepemimpinan, pelayanan publik, akuntabilitas, dan faktor-faktor yang mempengaruhi keberasilan reformasi birokrasi. Namun pada dasarnya, kajian-kajian tersebut substansinya sangat berkaitan dan berhubungan erat dengan praktik otonomi daerah. Seperti Sugiharto (2011) dalam kajiannya mengenai reformasi birokrasi menuju pemerintahan kelas dunia taun 2025 memberikan pemahaman yang lebih komprehensif mengenai reformasi birokrasi berdasarkan perspektif kebijakan grand design reformasi birokrasi, yang nantinya menjadi acuan bagi seluruh pemerintahan di daerah. Syamsuadi (2017) dalam kajian mengenai pelaksanaan reformasi birokrasi pasca otonomi daerah (studi pada Provinsi Riau) mengemukakan bahwa, reformasi birokrasi telah menjadi kebutuhan. Dalam peta otonomi daerah aparatur dituntut untuk dapat profesional, kompeten dan akuntabel, kendatipun dari hasil risetnya masih menunjukan bahwa untuk kasus di daerah Riau masih belum ideal oleh karena masih banyak ditemukannya penyimpangan terkait pelayanan publik.

Dari persoalan itu, riset kajian reformasi birokrasi berdasarkan tinjauan dari perspektif administrasi publik yang di lakukan Thahir (2018) menjadi cukup relevan. Melalui riset kajian pustakanya, Thahir menjelaskan bahwa, reformasi birokrasi yang dilakukan di beberapa Negara pada umumnya berkaitan dengan dua dimensi utama yang harus diperbaiki yakni, dimensi keorganisasian dan dimensi sumber daya manusia aparatur. Kemudian, kajian yang dilakukan Samin (2011) mengenai reformasi birokrasi setidaknya menyinggung keterkaitannya dengan otonomi daerah melalui perspektif administrasi negara yang menekankan pentingnya mengindahkan nilai dan prinsip good governance dan SDM aparatur yang berintegritas, berkompetensi, konsisten dan memiliki komitmen kuat. Pentingnya membangun sumber daya aparatur yang berintegiras di jelaskan juga oleh Sumardi (2011) melalui tulisannya mengenai sumber daya aparatur sebagai pelaku utama reformasi birokrasi, Sumardi menjelaskan bahwa, ada tiga hal yang harus diperhatikan dalam membangun sumber daya aparatur. Pertama, proses seleksi penerimaan pegawai berbasis integitras, Kedua, proses seleksi penerimaan pegawai berbasis kompetensi, Ketiga, proses penerimaan pegawai berbasis kinerja dan netral. Sejalan dengan Samin, riset kajian Hadi Sumarto (2015) mengenai model kepemimpinan dalam reformasi birokrasi pemerintah menjelaskan bahwa kesadaran dan komitmen pemimpin menjadi begitu penting, sebab pimpinan birokrasi merupakan key person untuk membawa perubahan pada reformasi birokrasi. Secara keseluruhan semua penjelasan tersebut menandakan beberapa hal penting yang sangat mempengaruhi keberhasilan pelaksanaan reformasi birokrasi.

Dalam riset tesis Susanto (2012) menjelaskan bahwa keberhasilan reformasi birokrasi dipengaruhi oleh beberapa faktor, termasuk faktor lingkungan internal, seperti rendanya komitmen pemimpin, rendanya kualitas SDM aparatur, sistem dan prosedur yang belum mendukung perubahan, dan pedoman kebijakan yang terlalu rigid dijalankan serta faktor-faktor khas lainnya seperti kesempatan untuk KKN dan ketidakjelasan target dan tujuan agenda reformasi birokrasi yang dilaksanakan. Hal ini sejalan dengan riset yang hampir serupa yang dilakukan Haribowo, Fefta dan Mardiyono, yang menekankan pada faktor internal yang mempengaruhi keberhasilan reformasi birokrasi. Sedangkan riset 
Ahmad, dkk, (2017) menjelaskan dalam riset analitiknya bahwa, keberhasilan reformasi birokrasi ditentukan oleh bagaimana cara penerapan perencanaan strategis dan pembelajaran organisasi, dan faktor internal organisasi menjadi faktor penentu keberhasilan reformasi birokrasi.

Dalam kajian tulisan ini, meninjau faktor-faktor yang mempengaruhi keberhasilan reformasi birokrasi sebelumnya, bahwa kecenderungan berhasil atau tidaknya reformasi birokrasi pun dapat ditinjau dari perspektif turunan lain dari teori organisasi, seperti Isomorfisme Institusional sebagai alat untuk memahami organisasi dari sudut pandang politik dan tata cara yang meliputi kehidupan suatu organisasi yang lebih modern. Ada tiga macam mekanisme untuk mengidentifikasi hal tersebut yakni, isomorfisma koersif (coercive), isomorfisma mimetik atau meniru-niru (mimetic), dan isomorfisma normatif (normative) yang biasanya berhubungan dengan profesionalisasi. Isomorfisma koersif merupakan hasil dari tekanan formal maupun informal yang diberikan pada organisasi dengan organisasi lainnya dimana mereka saling bergantung dan didalamnya terdapat fungsi organisasi. Isomorfisma meniru-niru terjadi ketika teknologi organisasi kurang dipahami ketika tujuan yang ambigu, atau ketika terdapat ketidakpastian lingkungan yang simbolik. Sedangkan isomorfisma normatif berkaitan dengan profesionalisme yang ditafsirkan sebagai perjuangan kolektif dari anggota organisasi untuk menentukan kondisi dan metoda kerja mereka, untuk mengontrol "produksi" dan untuk mengembangkan kognitif dan melegitimasi otonomi pekerjaan mereka (Sofyani \& Akbar, 2015).

\section{METODE}

Metodologi dalam kajian tulisan ini menggunakan metode kualitatif melalui pendekatan yuridis normatif-yuridis empiris dan institusional. Hal tersebut dilakukan guna mengetahui/menemukan kemungkinan adanya kesenjangan antara harapan dan kenyataan (masalah/gap/distingsi). Pengumpulan data dalam kajian ini dilakukan dengan teknik pengumpulan dokumen resmi yang bersumber dari data primer maupun data sekunder yang terpercaya. Adapun teknik analisis data yang digunakan dalam kajian ini dilakukan dengan menggunakan metode deskriptif interpretatif melalui modus pendekatan hermeneutik-fenomenologi (Ghony \& Almanshur, 2012). Hal tersebut dilakukan untuk menelaah fenomena juga data yang ada secara detil untuk kemudian dilakukan interpretasi (penafsiran) terhadap objek berdasarkan data yang diperoleh sehingga menghasilkan suatu kesimpulan untuk kemudian dilakukannya teknik triangulasi jika itu dimungkinkan dalam kajian ini guna untuk memeriksa keabsahan data (verifikasi) secara empirik.

\section{HASIL DAN PEMBAHASAN}

\section{Reformasi Birokrasi di Pemerintah Daerah Kabupaten Bandung Barat Sebagai Upaya Mewujudkan Good Governance Melalui Kerangka Otonomi Daerah.}

Untuk mengkaji dan membahas sejauhmana reformasi birokrasi di Kabupaten Bandung Barat sebagai upaya mewujudkan good governace melalui kerangka otonomi daerah, akan diurai berdasarkan perspektif hasil opini LKPD, integritas organisasi, akuntabilitas kinerja dan berdasarkan survei internal kapasitas aparatur. Opini LKPDTA (Laporan Keuangan Pemerintah Daerah) Kabupaten Bandung Barat pada awal-awal berdirinya penyelenggaraan pemerintahan, tepatnya pada periode 2008-2010 hanya mendapatkan opini dengan hasil predikat TMP atau disclaimer, itulah yang tempo hari lalu banyak menjadi sorotan publik dan para pengamat terkait kinerja pemerintah Kabupaten Bandung Barat.

Pada 2011 lalu, Kabupaten Barat mulai menunjukan adanya peningkatan dengan hasil opini WDP (Wajar Dengan Pengecualian), meskipun sampai dengan 2018 tidak 
menunjukan perubahan apapun yang signifikan sama sekali (flat). Meninjau tahun 2018, dengan target awal WTP hanya teralisasi dengan predikat opini WDP. Berdasarkan data LAKIP 2018 Kabupaten Bandung Barat, hal itu diindikasikan oleh karena belum optimalnya peningkatan kapasitas dan integritas organisasi berikut aparaturnya. Dalam hal ini, melalui analisis pengamatan dan interpretasi penulis sebagai peneliti dalam riset kajian ini, lebih cenderung mengarah pada rendahnya mentalitas aparatur yang rentan dipengaruhi faktor lingkungan dan budaya birokrasi. ${ }^{3}$ Hal itu sejalan dengan penelitian Deddi Fardian (2014) mengenai ketidakpastian lingkungan dan kompetensi sumberdaya manusia yang positif dapat mempengaruhi kinerja aparatur. Asumsi demikian juga dapat ditinjau lebih lanjut berdasarkan data hasil survei internal yang dilakukan Kemenpan-RB, terhadap integritas Organisasi Perangkat Daerah (OPD) Kabupaten Bandung Barat tahun 2018 di bawah ini.

Tabel 1. Survei Internal Kemenpan-RB terhadap Integritas Organisasi Tahun 2018

\begin{tabular}{clc}
\hline No & \multicolumn{1}{c}{ Komponen } & Indeks \\
\hline 1 & Budaya Organisasi dan Sistem Anti Korupsi & 3,18 \\
2 & Integritas terkait Pengelolaan SDM & 3,21 \\
3 & Integritas terkait Pengelolaan Anggaran & 3,19 \\
4 & Integritas Kesesuaian Perinitah Atasan dengan Aturan dan Norma & 3,20 \\
& $\quad$ Indeks Integritas Organisasi & $\mathbf{3 , 2 0}$ \\
\hline
\end{tabular}

Hasil indeks integritas organisasi pada tabel.1. di atas menunjukan bahwa, survei internal terhadap integritas organisasi perangkat daerah menunjukan hasil kurang memuaskan dengan capaian score indeks 3,20 dalam skala 0-4. Nilai angka tersebut masih di bawah standar minimal yang diatur Peraturan Menteri Pendayagunaan Aparatur Negara dan Reformasi Birokrasi Nomor 52 Tahun 2014 tentang Pedoman Pembangunan Zona Integritas Menuju Wilayah Bebas Dari Korupsi Dan Wilayah Birokrasi Bersih Dan Melayani, sebesar 3,60. Keadaan demikian menandakan, masih cenderung lemahnya integritas aparatur. Artinya, persepsi-persepsi seperti mengenai budaya KKN dan budaya seperti pathology birokrasi lainnya, masih menyisakan potensi peluang untuk dilakukan/dipikirkan, meskipun itu hanya sebagian kecil kemungkinannya. Namun, hal tersebut akan berdampak signifikan tergantung darimana dan dari siapa persepsi atau perilaku tersebut itu muncul melalui potensi dan pengaruhnya, dilihat dari status, posisi, dan budaya birokrasi di lingkungan Pemerintah Daerah Kabupaten Bandung Barat. ${ }^{4}$

Artinya, sekelas pejabat birokrat mempunyai potensi peluang yang cukup sangat besar untuk melakukan tindakan demikian. Itulah yang kemudian terjadi pada kasus korupsi tempo hari yang melibatkan pejabat bupati, maupun pejabat eselon lainnya di Kabupaten Bandung Barat. Kemudian untuk meninjau sejauh mana pelaksanaan reformasi birokrasi di Kabupaten Bandung Barat berjalan dengan hasil kinerja yang akuntabel, efektif dan efisien, maka instrument lainnya dapat di lihat dari sejauh mana akuntabilitas kinerja aparatur tersebut menunjukan hasil kinerjanya. Jika ditelaah lebih

\footnotetext{
3 Hal ini secara teoritis dapat dilacak berdasarkan pernyataan Amstrong, yang dikutip Sulistiyani dan Rosidah dalam Ismail, bahwa beberapa point dalam prinsip dasar pendekatan terhadap manajemen manusia diantaranya; dari kultur dan tujuan organisasi yang diharapkan akan memberikan pengaruh yang besar terhadap hasil pencapaian yang terbaik. Simak Ismail, "Etika Birokrasi (Perspektif Manajemen Sumberdaya Manusia)",(Cetakan 1;Malang; Intrans,2017),hlm.8. pada lingkungan internal dalam kategori kultur organisasi, mempengaruhi 3 hal; Nilai-Nilai Organisasi, Suasana Organisasi, dan Gaya Kepemimpinan. Simak lebih lanjut dalam Ismail, Ibid., hlm.27.

4 Sebagaimana Siagian (dalam Ismail,2017) memaparkan bahwa pontensi patologi birokrasi dapat timbul berdasarkan persepsi dan gaya manajerialnya. Sedangkan gaya kepemimpinan berkecenderungan dipengaruhi oleh kultur dan budaya organisasi yang berada di lingkungan internal. Simak lebih lanjut dalam Ismail, Ibid., hlm.27
} 
lanjut, berdasarkan data evaluasi akuntabilitas kinerja instansi pemerintah daerah Kabupaten Bandung Barat tahun 2017-2018 yang dilakukan Kemenpan-RB, menunjukan hasil di bawah ini.

Tabel 2. Hasil Evaluasi atas Akuntabilitas Kinerja Instansi Pemerintah Daerah Kabupaten Bandung Barat

\begin{tabular}{llccc}
\hline \multirow{2}{*}{ Komponen Yang Dinilai } & \multirow{2}{*}{ Bobot } & $\mathbf{2 0 1 7}$ & $\mathbf{2 0 1 8}$ \\
\hline 1 & Perencanaan Kinerja & 30 & 22,56 & 22,10 \\
2 & Penukuran Kinerja & 25 & 16,56 & 16,51 \\
3 & Pelaporan Kinerja & 15 & 9,96 & 10,46 \\
4 & Evaluasi Internal & 10 & 5,50 & 5,75 \\
5 & Capaian Kinerja & 20 & 10,30 & 10,90 \\
Nilai Hasil Evaluasi & $\mathbf{1 0 0}$ & $\mathbf{6 4 , 8 8}$ & $\mathbf{6 5 , 7 2}$ \\
Tingkat Akuntabilitas Kinerja & B & B \\
\hline \multicolumn{4}{c}{ Sumber; Data olahan Kemen PANRB }
\end{tabular}

Sumber; Data olahan Kemen PANRB

Meninjau data pada tabel di atas, berdasarkan hasilnya menunjukan capaian yang cukup baik meski belum mencapai target yang diharapkan, yakni kategori "BB" atau di sekitar nilai 70,01. Kondisi demikian disebabkan ole karena penerapan SAKIP (Sistem Akuntabilitas Kinerja Instransi Pemerintah) yang dijalankan pemerintah daerah Kabupaten Bandung Barat sebagai pelaksanaan dari manajemen kinerja di sektor publik belum sepenuhnya mampu menggambarkan efektivitas penggunaan anggaran yang berkorelasi dengan kinerja yang dihasilkan. Terutama yang berkaitan dengan penjabaran definisi kinerja pada perumusan sasaran strategis, kualitas indikator kinerja, serta kualitas pelaksanaan pemantauan dan evaluasi kinerja pada setiap perencanaan kerja yang ada baik itu Renstra maupun pada RPJMD.

Dalam hal ini secara umum, dapat diinterpretasikan bahwa rendahnya kualitas, kapasitas dan profesionalitas sumberdaya aparatur masih menjadi sumber kendala utama. Asumsi demikian tersebut, dapat dipertegas berdasarkan hasil survei internal yang dilakukan Kemenpan-RB terhadap Perangkat Daerah Kabupaten Bandung Barat, yang menyatakan bahwa, dari 119 sampel (orang) pegawai pemerintah daerah Kabupaten Bandung Barat atas integritas jabatan, terdapat 55 orang pegawai atau $46,22 \%$ pegawai yang tidak memahami tugas dan fungsi yang harus dilaksanakan serta tidak memahami ukuran keberhasilan pelaksanaan tugas. Sebanyak 59 orang pegawai atau $49,58 \%$ pegawai telah memahami tugas fungsi yang harus dilaksanakan namun tidak memahami ukuran keberhasilan pelaksanaan tugasnya. Serta 5 orang pegawai atau $4,20 \%$ pegawai yang memahami tugas fungsi yang harus dilaksanakan dan memahami pula ukuran keberhasilan pelaksanaan tugasnya.

Hasil survei tersebut menandakan bahwa kualitas dan kapasitas (kompetensi) sumber daya aparatur pemerintah daerah Kabupaten Bandung Barat menunjukan kenyataan mengkhawatirkan, yang harus segera diperbaiki melalui peningkatan kualitas aparatur. Dalam hal ini, analisis kebutuhan diklat aparatur menjadi kebutuhan mendesak untuk meminimalisir kesenjangan kompetensi aparatur (Ngindana \& Hermawan, 2019). Sebab, bagaimanapun juga hal tersebut berpengaruh besar terhadap hasil capaian kinerja di seluruh unit kerja yang ada (Satibi, 2012). Tidak hanya itu saja, selain kualitas dan kapasitas aparatur, bahwa lingkungan dan budaya kerja birokrasi pun harus mampu membentuk integritas dan mentalitas aparatur secara personal individu, ataupun sebaliknya, sehingga dengan hal itu setidaknya akan mampu mendorong hasil kinerja yang ingin diharapkan menjadi lebih baik lagi (Ismail, 2017). 
Berdasarkan penjelasan dan seluruh uraian sebelumnya, dapat diketahui bahwa reformasi birokrasi melalui praktik otonomi daerah yang dijalankan pemerintah daerah Kabupaten Bandung Barat sebagai bagian dari agenda pemerintah pusat dalam mewujudkan Good Governance, disamping membutuhkan banyak sekali perubahan dan perbaikan mendasar, terutama dalam segi kualitas dan kapasitas (kompetensi) sumberdaya manusia aparatur sebagai pelaksana penyelenggaraan pemerintahan, hal yang lebih penting lainnya lagi sebagai faktor penentu keberhasilan reformasi birokrasi yang perlu untuk lebih ditingkatkan kembali yakni, kemampuan manajerial yang mumpuni, serta adanya komitmen yang kuat dari pucuk pimpinan (sebagai salah satu bentuk integritas) untuk terus menerus melakukan perubahan terhadap budaya dan lingkungan internal organisasi kearah yang lebih positif (Damanhuri \& Jawandi, 2017). Hal itu perlu untuk dilakukan, guna mewujudkan apa yang menjadi harapan organisasi untuk dapat memberikan nilai (feedback) yang lebih baik terhadap masyarakat.

\section{Capaian Reformasi Birokrasi Di Pemerintah Daerah Kabupaten Bandung Barat.}

Pemerintah daerah kabupaten Bandung Barat sejauh ini telah melakukan upaya perbaikan terhadap seluruh aspek tatakelola penyelenggaraan pemerintahan, baik itu yang meliputi aspek manajemen maupun kelembagaan/organisasi, dsb, melalui agenda pelaksanaan reformasi birokrasi. Adapun, jika meninjau sejauh mana capaian reformasi birokrasi pemerintah daerah kabupaten Bandung Barat berdasarkan tinjauan data olahan hasil evaluasi Kemenpan-RB pada akhir 2018 lalu menunjukan bahwa, indeks reformasi birokrasi pemerintah daerah kabupaten Bandung Barat meraih score minim, dengan raihan nilai angka 54,22 yang masuk kedalam kategori nilai huruf "CC". Nilai capaian tersebut secara keseluruhan menginterpretasikan hasil yang cukup (memadai), namun demikian masih perlu banyak sekali perbaikan yang mendasar. Hasil evaluasi dan rinciannya dapat dilihat pada tabel di bawah ini.

Tabel 3. Hasil Evaluasi Penilaian Perangkat Daerah Kementerian PANRB Terhadap Organisasi Perangkat Daerah Kabupaten Bandung Barat

\begin{tabular}{clcc}
\hline No & \multicolumn{1}{c}{ KOMPONEN PENILAIAN } \\
KOMPONEN PENGUNGKIT & Bobot & Nilai \\
\hline 1 & Manajemen Perubahan & 5,00 & 1,05 \\
2 & Penataan Peraturan Perundang-Undangan & 5,00 & 2,71 \\
3 & Penataan dan Penguatan Organisasi & 6,00 & 0,99 \\
4 & Penataan Tatalaksana & 5,00 & 1,01 \\
5 & Penataan Sistem Manajemen SDM & 15,00 & 10,89 \\
6 & Penguatan Akuntabilitas & 6,00 & 3,20 \\
7 & Penguatan Pengawasan & 12,00 & 1,62 \\
8 & Peningkatan Kualitas Pelayanan Publik & 6,00 & 4,15 \\
Total Komponen Pengungkit (A) & $\mathbf{6 0 , 0 0}$ & $\mathbf{2 5 , 6 1}$ \\
\hline BOMPONEN HASIL & \multicolumn{3}{c}{} \\
\hline 1 & Nilai Akuntabilitas & 14,00 & 9,08 \\
2 & Survei Internal Integritas Organisasi & 6,00 & 3,73 \\
3 & Survei Eksternal Persepsi Korupsi & 7,00 & 5,83 \\
4 & Opini BPK & 3,00 & 2,00 \\
5 & Survei Eksternal Pelayanan Publik & 10,00 & 7,98 \\
Total Komponen Hasil (B) & $\mathbf{4 0 , 0 0}$ & $\mathbf{2 8 , 6 2}$ \\
Indeks Reformasi Birokrasi (A+B) & $\mathbf{1 0 0 , 0 0}$ & $\mathbf{5 4 , 2 2}$ \\
\hline
\end{tabular}

Sumber; Laporan KemenPAN RB Tahun 2018

Pada tabel 3. di atas dapat dijelaskan bahwa dalam teknis penilaian reformasi birokrasi dibagi kedalam 2 klasifikasi pembagi. Yang pertama, komponen pengungkit sebagai tahapan proses dengan nilai bobot 60,00, dan yang kedua, komponen pada 
tataran hasil dengan nilai bobot 40,00. Dalam tabel penilaian tersebut dapat diketahui bahwa hampir semua komponen tidak mencapai target. Beberapa nilai paling rendah yang cenderung sangat jauh dari target capaian pada komponen pengungkit, diantaranya:

\section{a. Manajemen Perubahan}

Hasil evaluasi ini meraih skor sangat minim dengan nilai 1,05 dari 5,00. Komponen penilaian ini diukur, berdasarkan beberapa perangkat indikator yang meliputi, tim reformasi birokrasi, road map reformasi birokrasi, pemantauan dan evaluasi reformasi birokrasi, perubahan pola pikir dan budaya kinerja. Berdasarkan data laporan hasil evaluasi Kementerian PANRB, hasil capaian tersebut sebagian besar oleh karena, belum terbentuknya tim reformasi birokrasi, belum ditetapkannya dokumen road map reformasi birokrasi, belum dilaksanakannya pemantauan reformasi birokrasi yang dituangkan kedalam rencana aksi tindak-lanjut termasuk juga atas pelaksanaan quick win reformasi birokrasi, dan penerapan agen perubahan yang belum dilaksanakan (role model) serta belum memperlihatkan perbaikan substantif yang berdampak pada perbaikan tata kelola pemerintahan. Hal ini dapat sedikit menandakan bahwa, produktivitas, profesionalitas, dan motivasi kinerja aparatur masih sangat rendah.

\section{b. Penataan Perundang-Undangan}

Hasil evaluasi ini meraih skor minim dengan nilai 2,71 dari 5,00. Komponen penilaian ini diukur, berdasarkan beberapa perangkat indikator yang meliputi, harmonisasi, sistem pengendalian dalam penyusunan peraturan perundang-undangan. Berdasarkan hasil evaluasi Kementerian PANRB capaian tersebut sebagian besar oleh karena, belum adanya identifikasi, pemetaan, dan evaluasi atas keharmonisan terhadap seluruh peraturan perundang-undangan yang masih berlaku. Hal ini dapat sedikit menandakan, tingkat kepatuhan aparatur terhadap kebijakan yang berlaku, serta adaptabilitasnya berdasarkan perubahan yang ada dilingkungan kerja masih sangat rendah.

\section{c. Penataan dan Penguatan Organisasi}

Hasil evaluasi ini meraih skor sangat minim dengan nilai 0,99 dari 6,00. Komponen penilaian ini diukur, berdasarkan beberapa perangkat indikator yang meliputi, organisasi yang tepat ukuran dan tepat fungsi, serta penataan. Berdasarkan data hasil evaluasi Kementerian PANRB capaian tersebut sebagian besar oleh karena, tidak adanya keselarasan antara penyusunan kelembagaan perangkat daerah dengan RPJMD, yang dititikberatkan pada kesesuaian antara kinerja yang diharapkan dengan ukuran organisasi, sehingga, performance based organization tidak terwujud. Hal ini secara normatif dapat menandakan bahwa kualitas dan kapasitas dari sumberdaya aparatur masih sangat rendah yang merujuk pada kompetensi aparatur pegawai. Selain itu, perbedaan kepentingan pada setiap unit kerja pun dapat mempengaruhi faktor keberhasilan point ini (Putra, 2015).

\section{d. Penataan Tatalaksana}

Hasil evaluasi ini meraih skor sangat minim dengan nilai 1,01 dari 5,00. Komponen penilaian ini diukur, berdasarkan beberapa perangkat indikator yang meliputi, proses bisnis dan prosedur operasional tetap (SOP) kegiatan utama, e-government, dan keterbukaan informasi publik. Berdasarkan data hasil evaluasi Kemenpan-RB capaian tersebut sebagian besar oleh karena, belum disusunnya peta proses bisnis dan ditetapkan berdasarkan kinerja yang diharapkan akan dicapai dalam RPJMD, sebagian besar perangkat daerah belum menyusun SOP, belum terintegrasikannya sistem perencanaan, penganggaran dan kinerja ke dalam e-government. Hal ini dapat 
menandakan bahwa, produktivitas, profesionalitas, dan motivasi kinerja aparatur masih sangat rendah yang merujuk pada perlunya adanya sosok pemimpin yang mempunyai komitmen dan perhatian tinggi terhadap kebutuhan unit kerja dan perilaku seluruh pegawai. Kondisi demikianlah yang kemudian nantinya akan sangat berpengaruh terhadap hasil ukuran capaian kinerja, layanan administratif, dan penilaian organisasional.

\section{e. Penguatan Akuntabilitas}

Hasil evaluasi ini meraih skor sangat minim dengan nilai 3,20 dari 6,00. Komponen penilaian ini diukur, berdasarkan beberapa perangkat indikator yang meliputi, keterlibatan pemimpin dan pengelolaan akuntabilitas kinerja. Berdasarkan hasil yang ada sesuai dengan penjelasan pada tabel.4, capaian tersebut sebagian besar oleh karena, rendahnya kualitas (manajerial), kapasitas dan profesionalitas sumberdaya aparatur masih menjadi sumber kendala yang paling utama. Dalam hal ini, perubahan yang terjadi tidak hanya harus memperhatikan tataran regulasi yang diberlakukan, akan tetapi komitmen manajemen justru menjadi sangat penting ,oleh karena hal tersebutlah yang sangat berpengaruh signifikan terhadap penguatan akuntabilitas (Ahyaruddin \& Akbar, 2017).

\section{f. Penguatan Pengawasan}

Hasil evaluasi ini meraih skor sangat minim dengan nilai 1,62 dari 12,00. Komponen penilaian ini diukur, berdasarkan beberapa perangkat indikator yang meliputi, gratifikasi, penerapan spip, pengaduan masyarakat, whistle-blowing system, penanganan benturan kepentingan, pembangunan zona integritas. Berdasarkan data hasil evaluasi Kementerian PAN-RB capaian tersebut sebagian besar oleh karena, sistem integritas belum sepenuhnya dilaksanakan, terutama terkait, pengendalian gratifikasi, penerapan SPIP, penanganan pengaduan masyarakat, penerapan WhistleBlowing System dan benturan kepentingan, serta pelaksanaan pembangunan Wilayah Bebas dari Korupsi/Wilayah Birokrasi Bersih dan Melayani (WBK/WBM) belum dilakukan. Kondisi demikian sama halnya seperti dalam penelitian Herbasuki di Kabupaten Pekalongan yang menyatakan bahwa penerapan SPIP terhambat oleh, rendahnya kompetensi aparatur, tingkat ketidakpatuhan yang tinggi terhadap regulasi kebijakan yang rentang dipengaruhi kepentingan (Herbasuki, 2015). Hal ini dapat menandakan bahwa, peluang dan potensi kecurangan terkait KKN masih sangat besar kemungkinan untuk dilakukan aparatur.

Sedangkan komponen dengan nilai yang cenderung tidaklah jauh dari target yang diharapkan, diantaranya:

\section{a. Penataan Sistem Manajemen SDM}

Hasil evaluasi ini meraih nilai 10,89 dari 15,00. Komponen penilaian ini diukur, berdasarkan beberapa perangkat indikator yang meliputi, perencanaan kebutuhan pegawai sesuai dengan kebutuhan, proses penerimaan pegawai transparan, objektif, akuntabel dan bebas KKN, pengembangan pegawai berbasis kompetensi, promosi jabatan dilakukan secara terbuka, penetapan kinerja individu, penegakan aturan disiplin/kode etik/kode perilaku pegawai, pelaksanaan evaluasi jabatan, dan sistem informasi kepegawaian. Berdasarkan data hasil evaluasi Kemenpan-RB, beberapa yang harus diperhatikan dalam hal ini yakni, ukuran kinerja individu pada beberapa perangkat daerah belum menggambarkan cascade kinerja dari organisasi, masih terdapat perbedaan antara ukuran kinerja individu dengan tolok ukur keberhasilan yang dituangkan dalam dokumen Sasaran Kerja Pegawai (SKP), kebutuhan pengembangan kompetensi pegawai belum diidentifikasi. Hal ini dapat menandakan, adanya ketidakmampuan aparatur didalam menjabarkan tugas pekerjaan yang 
menjadi ukuran keberhasilannya. Artinya, kualitas, kapasitas dan profesionalitas sumberdaya individu (kompetensi aparatur) aparatur masih menjadi sumber kendala. Selain itu, dalam kondisi seperti ini pun, lingkungan internal dan budaya/kultur organisasi akan sangat berpengaruh terhadap kemampuan aparatur.

\section{b. Peningkatan Kualitas Pelayanan}

Hasil evaluasi ini meraih nilai 4,15 dari 6,00. Komponen penilaian ini diukur, berdasarkan beberapa perangkat indikator yang meliputi, standar pelayanan, budaya pelayanan prima, pengelolaan pengaduan, penilaian kepuasan terhadap pelayanan, pemanfaatan teknologi informasi. Berdasarkan data hasil evaluasi Kemenpan-RB, beberapa yang harus diperhatikan dalam hal ini yakni, belum adanya dokumen Standar Pelayanan (SP) hampir disetiap perangkat daerah, perbaikan kualitas pelayanan publik belum didukung dengan perbaikan proses bisnis, masih sangat rendahnya kualitas SDM yang menunjang perbaikan pelayanan publik.

Hal tersebut dapat ditinjau berdasarkan data Kemenpan-RB, pada survei eksternal terhadap masyarakat yang telah merasakan pelayanan oleh Pemerintah Kabupaten Bandung Barat yang menunjukan hasil bahwa (1) Survei persepsi pelayanan menunjukan indeks dengan score 3,19 dalam skala 4. Hasil survei tersebut menunjukan masih terdapat selisih atau gap antara harapan penerima layanan dengan realitas kondisi layanan yang diterima, (2) Survei persepsi anti korupsi yang merupakan gambaran atas integritas pemberi layanan menunjukan indeks 3,33 dalam skala 4 . Kondisi tersebut menunjukan bahwa masyarakat masih memiliki persepsi bahwa integritas aparatur pemberi layanan masih perlu ditingkatkan kembali.

Seluruh uraian di atas merupakan penjelasan dari capaian komponen proses (Pengungkit) pelaksanaan reformasi birokrasi yang pada analisisnya ditemukan gejalagejala apa saja yang menandakan penyebab tidak tercapainya target pada komponen proses (pengungkit) agenda perubahan reformasi birokrasi. Hasil capaian komponen pengungkit ini dapat dikatakan sebagai komponen yang sebagian besar akan sangat mempengaruhi komponen hasil. Berdasarkan hasil komponen proses (Pengungkit) sebelumnya maka yang menjadi komponen hasil dari pelaksanaan reformasi birokrasi di Pemerintah Daerah Kabupaten Bandung Barat, mencakup 3 aspek yang diantaranya:

a. Terwujudnya pemerintahan yang bersih dan bebas KKN. Yang diukur berdasarkan (1) Nilai persepsi korupsi (Survei Internal). Hasil evaluasi ini meraih nilai 5,83 dari 7,00. Hal ini dapat menandakan bahwa gejala-gejala KKN masih memiliki potensi peluang yang cukup besar untuk terjadi kedepannya; dan (2) Opini BPK atas laporan keuangan Instansi pemerintah. Hasil evaluasi ini meraih nilai 2,00 dari 3,00. Hal ini dapat menandakan masih rendahnya mentalitas aparatur yang sangat rentan dipengaruhi lingkungan internal dan budaya organisasi.

b. Terwujudnya peningkatan kualitas pelayanan publik kepada masyarakat. Komponen ini diukur berdasarkan, nilai persepsi pelayanan (survei eksternal). Hasil evaluasi ini meraih nilai 7,98 dari 10,00. Hal ini dapat menandakan bahwa kualitas pelayanan publik masih dipandang tidak sesuai dengan yang diharapkan masyarakat, artinya, potensi adanya gejala malpraktik administrasi-pelayanan publik masih terbilang cukup besar.

c. Meningkatnya kapasitas dan akuntabilitas kinerja birokrasi. Yang diukur berdasarkan (1) Nilai akuntabilitas kinerja. Hasil evaluasi ini meraih nilai 9,08 dari 14,00. Hal ini dapat menandakan adanya ketidakmampuan dari sumberdaya aparatur didalam menjelaskan kondisi-kondisi penyelenggaraan pemerintahan dalam perspektif akuntabilitas publik berdasarkan aktivitas-kegiatan yang 
dilakukan. Kondisi ini sangat rentan berkaitan dengan indikasi adanya gejala-gejala patologi birokrasi; dan (2) Nilai kapasitas organisasi (survei internal). Hasil evaluasi ini meraih nilai 3,73 dari 6,00. Hal ini dapat menandakan bahwa kapasitas dan profesionalitas sumberdaya aparatur masih menjadi sumber kendala utama.

Berdasarkan seluruh uraian yang telah dijelaskan, dapat di interpretasikan bahwa, Reformasi Birokrasi yang dilaksanakan Pemerintah Daerah Kabupaten Bandung Barat belumlah menunjukan hasil yang optimal untuk saat ini.

\section{KESIMPULAN}

Reformasi Birokrasi yang dijalankan pemerintah daerah Kabupaten Bandung Barat melalui praktik otonomi daerah sejauh ini, belum menunjukan tanda-tanda ke-arah yang lebih optimal dalam upaya mewujudkan Good Governance. Hal itu secara a posteriori cukup jelas ditandai dengan adanya fenomena korupsi para pejabat aparatur sebagai implikasinya. Kondisi demikian dapat ditinjau berdasarkan data empiris hasil opini LKPD yang belum menunjukan perubahan ke arah yang lebih baik, hasil survei integritas organisasi yang menggambarkan persepsi para pegawai aparatur di lingkungan kerja pun belum menunjukan hasil yang baik, kemudian hasil akuntabilitas kinerja yang masih perlu untuk ditingkatkan kembali integritasnya serta hasil survei internal kapasitas aparatur yang belum menunjukan hasil capaian yang optimal sebagaimana representasi dari kompetensi aparatur yang layak. Kemudian, secara rasional-positivism ketidakoptimalan pelaksanaan reformasi birokrasi ditandai dengan capaian pelaksanaan reformasi birokrasi pemerintah daerah Kabupaten Bandung Barat yang hasilnya masih sangat jauh dari target yang diharapkan. Dalam persoalan tersebut secara normatif kualitas (kompetensi) sumber daya aparatur menjadi kendala utama, disertai hal lainnya yang bersifat mimetic dan koersif yang juga turut serta mempengaruhi mentalitas aparatur secara keseluruhan berdasarkan kepentingannya seperti pengaruh pimpinan, budaya dan lingkungan birokrasi. Maka dari itu, untuk mengawal persoalan ini akan menjadi lebih komprehenshif lagi apabila riset kajian ini dilengkapi dengan kajian-kajian lebih mendalam yang bertemakan Implementation melalui perspektif proses penerapan/pelaksanaan kebijakan reformasi birokrasi, dan selanjutnya bila perlu disertai dengan riset-riset dan kajian-kajian yang bertemakan Analysis of the result of Implementation reformasi birokrasi melalui perspektif interpretatif-deskriptif.

\section{DAFTAR RUJUKAN}

\section{Buku:}

Dwiyanto, A. (2010). Reformasi Birokrasi Publik di Indonesia. Yogyakarta: Gajahmada University Press.

Ghony, M. D., \& Almanshur, F. (2012). Metode Penelitian Kualitatif. (R. T. Sari, Ed.) Jogjakarta, Jawa Tengah, Yogyakarta: Ar-Ruzz Media.

Ismail. (2017). Etika Birokrasi "Perspektif Manajemen Sumberdaya Manusia". Malang: Intrans.

Moenek, R., \& Suwanda, D. (2019). Good Governance (Pengelolaan Keuangan Daerah). Bandung: PT. Remaja Rosdakarya.

Satibi, I. (2012). Manajemen Publik. Bandung: Unpas Press.

Sedarmayanti. (2012). Good Governance (Edisi Revisi ed.). Bandung: Cv.Mandar Maju.

Thoha, M. (2014). Birokrasi Pemerintah Indonesia di Era Reformasi (1 ed.). Jakarta: Kencana Prenadamedia Group. Dipetik Februari 11, 2020 


\section{Jurnal:}

Ahmad, M., Budinningsihh, I., Sukamto, H., \& Suyanto, B. (2017). Faktor-Faktor Yang Mempengaruhi Keberhasilan Reformasi Birokrasi Di Lembaga Pemerintah. International Journal of Economic Research (IJER), 1-16.

Ahyaruddin, M., \& Akbar, R. (2017). Akuntabilitas dan kinerja instansi pemerintah: Semu atau nyata? Jurnal Akuntansi \& Auditing Indonesia, 21(2), 105-117. doi:https://doi.org/10.20885/jaai.vol21.iss2.art3

Damanhuri, \& Jawandi, R. (2017). Reaktualitasi Reformasi Birokrasi Menuju Good Governance. Prosiding Seminar Nasional Pendidikan FKIP UNTIRTA 2017, (hal. 297304).

Fardian, D. (2014). Pengaruh Faktor Politik, Ketidakpastian Lingkungan Dan Kompetensi Sumber Daya Manusia Terhadap Penerapan Transparansi Pelaporan Keuangan (Studi Empiris atas SKPD Pemerintah Kota Padang). Jurnal Akuntansi, 3(1), 1-18.

Hadi Sumarto, R. (2015, Februari). Model Kepemimpinan Dalam Reformasi Birokrasi Pemerintah. Efisiensi, XIII, 1-15. Diambil kembali dari http://journal.uny.ac.id/index.php/efisiensi

Herbasuki. (2015). Identifikasi Kondisi dan Upaya Penguatan Pengawasan Dalam Rangka Reformasi Birokrasi Di Kabupaten Pekalongan. Jurnal Manajemen Dan Kebijakan Publik, 1(1), 31-44. doi:https://doi.org/10.14710/gp.1.1.2015.31-44

Jati, W. R. (2012). Inkonsistensi Paradigma Otonomi Daerah di Indonesia : Dilema Sentralisasi atau Desentralisasi. Konstitusi, 9, 744-769.

Lestari, R. A. (2019). Reformasi Birokrasi Sebagai Pelayanan Publik. Jurnal Dinamika Governance FISIP UPN "Veteran", 9, 62-68. doi: https://doi.org/10.33005/jdg.v9i1.1421

Ngindana, R., \& Hermawan, R. (2019, April). Analisis Kebutuhan Diklat Pegawai Negeri Sipil Berbasis Kesenjangan Kerja Unit Kerja Di Lingkungan Pemerintah Kota Mojokerto. JISOP "Jurnal Inovasi Ilmu Sosial dan Politik", 1(1), 1-11. doi:http://dx.doi.org/10.33474/jisop.v1i1.2669

Putra, S. A. (2015). Reformasi Birokrasi Bidang Organisasi dan Tata Laksana Di Kementerian Kelautan dan Perikanan Jakarta. JISIP: Jurnal Ilmu Sosial dan Ilmu Politik, 4(1), 11-19.

Radiansyah, R. (2019). Faktor-Faktor Yang Mempengaruhi Pelaksanaan Otonomi DaerahPada Sektor Bidang Kesehatan Di Kabupaten Bandung Barat. JISIPOL / Jurnal Ilmu Sosial Dan Ilmu Politik, 3, 1-15. Dipetik 1 12, 2020, dari http://ejournal.unibba.ac.id/index.php/jisipol/article/view/12

Rahmatunissa, M. (2019). Dialektika Konsep Dynamic Governance. Jurnal Academia Praja, 2(02), 3-4. doi:https://doi.org/https://doi.org/10.36859/jap.v2i02.116

Samin, R. (2011). Reformasi Birokrasi. Jurnal Fisip UMRAH, 2, 172-182.

Sofyani, H., \& Akbar, R. (2015). Hubungan Karakteristik Pegawai Pemerintah Daerah dan Implementasi Sistem Pengukuran Kinerja: Perspetif Isomorfisma Institusional. Jurnal Akuntansi $\& \quad$ Auditing Indonesia, 19, 193-173. doi:https://doi.org/10.20885/jaai.vol19.iss2.art6

Sugiharto, G. (2011). Reformasi Birokrasi Menuju Pemerintahan Kelas Dunia Tahun 2025. Pendayagunaan Aparatur Negara, 5-22.

Sumardi. (2011). Sumber Daya Aparatur Sebagai Pelaku Utama Reformasi Birokrasi. Jurnal Pendayagunaan Aparatur Negara, 1, 68-76.

Susanto, S. (2012). Faktor-Faktor Internal Yang Mempengaruhi Pelaksanaan Kebijakan Reformasi Birokrasi Departemen Keuangan. Jakarta. Diambil kembali dari http://lib.ui.ac.id/file?file=digital/20300497-T30497-Satya\%20Susanto.pdf 
Syamsuadi, A. (2017). Kajian Pelaksanaan Reformasi Birokrasi Pasca Otonomi Daerah (Studi pada Provinsi Riau).

Thahir Haning, M. (2018, Juni). Reformasi Birokrasi di Indonesia: Tinjauan Dari Perspektif Administrasi Publik. JAKPP (Jurnal Analisis Kebijakan dan Pelayanan Publik), 4, 25-37.

\section{Artikel Daring:}

Bebey, A. (2019, Desember 4). "Korupsi Dana BPJS, Mantan Pejabat RSUD di Bandung Barat dan Anak Buah Di Penjara". Bandung Barat, Jawa Barat: Merdeka.com. Diambil kembali dari https://www.merdeka.com/peristiwa/korupsi-dana-bpjs mantanpejabat-rsud-di-bandung-barat-dan-anak-buah-dipenjara.html

Damanhuri, \& Jawandi, R. (2017). Reaktualitasi Reformasi Birokrasi Menuju Good Governance. Prosiding Seminar Nasional Pendidikan FKIP UNTIRTA 2017, (hal. 297304). Diambil kembali dari http://jurnal.untirta.ac.id/index.php/psnp/article/view/297-304

Tim Tagar.id. (2018). Ciduk Bupati Bandung Barat KPK Amankan Rp.435 Juta. Kabupaten Bandung Barat. Retrieved January 20, 2020

\section{Undang-Undang dan Peraturan Pemerintah:}

Peraturan Presiden Republik Indonesia Nomor 81 Tahun 2010 Grand Design Reformasi Birokrasi 2010-2025. 21 Desember 2010. Deputi Sekretariat Kabinet Bidang Hukum Republik Indonesia. Jakarta.

Kementerian Pendayagunaan Aparatur Negara dan Reformasi Birokrasi Nomor B/302/RB.06/2018. Perihal. Hasil Evaluasi Atas Pelaksanaan Reformasi Birokrasi Pemerintah Daerah Kabupaten Bandung Barat 2018.

Kementerian Pendayagunaan Aparatur Negara dan Reformasi Birokrasi Nomor B/1116/AA.05/2018. Perihal. Hasil Evaluasi Atas Akuntabilitas Kinerja Instansi Pemerintah Daerah Kabupaten Bandung Barat 2018.

Kabupaten Bandung Barat.2018. Laporan Akuntabilitas Kinerja Instansi Pemerintah. Maret.Kabupaten Bandung Barat. 